\title{
A Brief Analysis of the Disputes Arising from China-African Civil and Commercial Transactions*
}

\section{Weidong ZHU}

Professor, Deputy Director, Centre for African Laws and Society; Director, African Financial Laws Institute of the Centre for Finance and Law, Xiangtan University

Email: zwd94@sina.com

\begin{abstract}
:
With the frequent civil and commercial transactions between China and Africa, more and more legal disputes arose as a result. Currently the civil and commercial disputes are mainly the contractual disputes, letter of credit or guarantee disputes, labor disputes, marine disputes and delictual disputes. These disputes often occur in the African countries and are often settled in African courts or arbitral institutions. Under the current legal systems and legal traditions in many African countries and in China, it is more preferable to settle such disputes through arbitration instead of through litigation for the Chinese parties as well as for the African parties doing business in China.
\end{abstract}

Key Words: Disputes, China-African civil and commercial transactions, Litigation, Arbitration

\footnotetext{
* The paper is part of the research project sponsored by the China Social Science Research Fund (Project No. 08CFX055). The views expressed in this paper remain the author's, they do not represent any government or organization. This paper was submitted to and read at the First China-African Think Tank Forum held in Hangzhou on 27-29 October, 2011. The author thanks those who have made valuable comments on this paper during the forum.
} 


\section{INTRODUCTION}

China is the largest developing country and Africa is the continent that has the largest numbers of the developing countries in the world, they have great potential in cooperation with the strong complementarity in their economy. As a result, the civil and commercial transactions between the Chinese legal or natural persons with their African counterparts become increasingly frequent. The trade volume between both sides reached over US $\$ 10$ billion in 2000 when the first Forum on China-African Cooperation was held in Beijing. Since then, the China-African trade grows on a fast speed, in 2008 the trade volume surpassed US\$100 billion and last year witnessed a China-African trade volume over US\$160 billion. Since 2009, China has become the largest trading partner with Africa. At the same time, the investment from China to Africa grew at an unprecedented rate. The investment from China to Africa was only US\$210 million in 2000 but in 2009 it has reached US\$1.44 billion. By the end of 2011, the total investment from China to Africa has reached over US\$40 billion, including direct investment of US $\$ 14.7$ billion. There are currently over 2000 Chinese enterprises doing business in Africa which is now the fourth largest investment destination for China.

On the other hand, more and more African enterprises and persons came to China to exploit the booming business opportunity, and by the end of 2009, the investment from Africa to China was US\$9.93 billion. ${ }^{1}$ In Zhejiang Province---a province in the east of China which has close business relations with Africa---463 enterprises were established by the investors from Africa in $2010 .^{2}$ Nearly 400 trading agencies have been set up by the African people in Yiwu, a city in Zhejiang Province well-known for its small commodities, over 1000 African people working there. In Guangzhou, another city in the south of China, more than 80,000 African people are pursuing their fortune there.

With the fast development of business relations between both sides in recent years, the civil and commercial communications between both sides become more and more frequent, as can be seen from above, having resulted in large amounts of disputes. Whether the disputes can be settled efficiently, effectively and reasonably will have a great impact on the development of business relations. The author will first analyze the types of such disputes, and then will probe their features; finally, the author will propose the way to settle such disputes.

\section{THE TYPES OF THE DISPUTES ARISING FROM CHINA-AFRICAN CIVIL AND COMMERCIAL RELATIONS}

The author has collected many judgments rendered by the Southern African courts involving the Chinese parties and the judgments involving the African parties rendered by the Chinese

\footnotetext{
1 The White Paper on the China-African Business Relationship (2010).

${ }^{2}$ Yuan Beixi, The Cooperation between Zejiang and Africa Came to a New Stage, Zejiang Daily, May 17, 2011.
} 
courts, and the author has also given some legal advice to the Chinese parties doing business in Africa and to the African parties doing business in China. Additionally, the author has once designed a questionnaire about the legal issues relating to doing business in Africa and received some feedbacks from the Chinese enterprises doing business in Africa. Based on the judgments and feedbacks from the questionnaire, the legal disputes arising from China-African civil and commercial transactions can be classified into the following main categories:

\subsection{Contractual disputes}

This is the main type of the disputes in the China-African civil and commercial transactions. Six disputes arose from the performance of contract among the over 30 cases collected and advised on. According to the feedbacks from the questionnaire, the disputes that the Chinese enterprises encountered in Africa are also mainly contractual ones. While in the contractual disputes, the disputes arising from the sales contract and investment contract rank on the top due to the fact that the China-African business transactions involve mainly the sales of goods and investments; and most of the investment contractual disputes are out of construction contract because of the quantities of infrastructure projects that the Chinese enterprises are carrying on in Africa. A group of data can illustrate the fact well: in the 89 cases that the Cairo Regional Centre for International Commercial Arbitration accepted in 2009 and in the first half year of 2010, the sales contractual cases and construction cases covers $33 \%$ of the total number; and in the 89 cases, the number of the cases involving the Chinese parties (11\%) is just below that involving the German parties $(12 \%)^{3}$

\subsection{Disputes from the letter of credit or the letter of guarantee}

Letter of credit and the letter of guarantee or the standby letter of credit is widely used in the business world. Payment by the letter of credit is often stipulated in the sales contracts between the Chinese and the African parties, while in the project contracts between both sides the African party usually requires the Chinese party to provide the guarantee for the advance payment and for the performance issued by the banks. Therefore, the disputes relating to the acceptance or the payment of the letter of credit or letter of guarantee will occasionally arise. For example, a case that the High People's Court of Jiangsu Province, China dealt with in 2001 between the Nedbank, South Africa and the Foreign Trading Company of Huaiyin City, Jiangsu concerned the acceptance and payment of a letter of credit. ${ }^{4}$ Soon after the Chinese companies'

\footnotetext{
${ }^{3}$ CRCICA Annual Report (2009-2010). The author thanks Dr Mohamed Abdel Raouf, Director of the Centre, for sending me a copy of the report. The Centre accepted 51 international cases in 2009 and 66 in 2010, with an annual increase of 35\%. In the first half year of 2011, the Centre accepted another 30 new cases. Among the 66 cases accepted in 2010, the construction contract cases rank at the top, $47 \%$ of the total cases. Considering the rapid development of China-African business relations, the Centre is planning to strengthen cooperation with the China Law Society and the China International Economic and Trade Arbitration Commission (CIETAC), to see Report on the AALCO's Regional Arbitration Centre at the $50^{\text {th }}$ annual session of the Asian-African Legal Consultative Organization held in Colombo, Sri Lanka from 27 June to $1^{\text {st }}$ July, 2011, available at: http://www.aalco.int/content/50thannualsession

${ }^{4}$ The Institute for the Applied Legal Science of the Supreme People's Court, Selected Judgements of the People's
} 
withdraw from Libya and suspension of the infrastructure projects there, some Libyan banks requested the postponement of 11 advance payment guarantee deadlines, involving eight Chinese construction projects and a total of US\$497 million. For eight of the guarantees, the banks offered the options to either repay the advance payment principle and interest, or postpone the deadline to the end of next year.

\subsection{Labor disputes}

Labor disputes are the most headache issues for the Chinese enterprises doing business in Africa. In the examined judgments made by the Southern African courts, 9 judgments involve the labor disputes, 6 judgments were rendered by the court of Lesotho ${ }^{5}$ and the other 3 judgments were rendered by the courts of Zimbabwe, ${ }^{6}$ Malawi $^{7}$ and Botswana ${ }^{8}$, respectively. Most of the disputes resulted from the Chinese companies' non-abidance by the local strict labor laws, which should arose the attention from the relevant Chinese governmental institutions.

\subsection{Marine Disputes}

Many ports in the African countries such as the Durban, Cape Town, Lagos, Alexandria are very important along the international sea carriage lines and the ships from other countries often harbour there, including the ships from China. According to the provisions of the marine jurisdiction in many African countries, the ships may be attached for some legal reasons. Many Chinese ships have been attached in the past few years in the African ports, especially in South Africa, giving rise to many marine disputes. ${ }^{9}$

\subsection{Delictual disputes}

Among the 30 judgments made by the Southern African courts involving the Chinese parties, there are 4 delictual disputes involving unlawful act of assault, ${ }^{10}$ damages to

\footnotetext{
Courts, vol.4, 2001.

${ }^{5}$ Factory Workers Union v. YZICC Clothing Manufacturers (Pty) Ltd, (LC/20/2004) [2008] LSLC 8; Hong Shun Import and Export (Pty) Ltd v. Lerotholi and Another (LC/REV/81/08, Ao297/08) [2010] LSLC 12; Labor Commissioner v. Lesotho Carton (Pty) Ltd (LC/64/04) [2005] LSLC 5; Afro-Asia Engineering (Pty) Ltd v. Matsela and Another (LC/REV/65/06) [2006] LSLC 16; Sun Textile (Pty) Ltd v. Direcotorate of Dispute Prevention and Resolution and Another (LC/REV/422/2006) [2008] LSLC 17; Factory Workers Union v. Ever Unison Garments (Pty) Ltd (LC/7/04) [2006] LSLC 4.

${ }^{6}$ Manhanga v Haulong Construction (Private) Limited (HC 10599/2000) [2002] ZWHHC 2; HH 2-2002 (9 January 2002).

${ }^{7}$ Tumbe v. Chinese Engineering and Furniture (IRC 334 of 2002) [2007] MWIRC 85.

${ }^{8}$ Tunhira v B.L. Moalosi Enterprises (Pty) Ltd (IC.M 12/2005) [2006] BWIC 1; [2006] 1 BLR 167 (1 January 2006).

${ }^{9}$ Great River Shipping v. Sunnyface Marine 1992 (4) SA 313 (C); International Marine Transport SA v. MV ' Le Cong", case No. 080/05, the Supreme Court of South Africa; another Chinese ship was attached by the Durban Court, South Africa on 26 August 1999, to see http://www.civillaw.com.cn/article/default.asp?id=9896.

${ }^{10}$ Mrs Yuping Lee v. Mr Wu YaoZheng, Civil Side No. 54 of 2002, in the Supreme Court of Sychelles.
} 
reputation, ${ }^{11}$ infringement of trade mark $^{12}$ and unlawful competition ${ }^{13}$, rendered by the Supreme Court of Seychelles, the High Courts in South Africa, Uganda and Lesotho, respectively.

\subsection{Family issues}

The rapid development of the civil and commercial communications between China and African countries also led to more and more cross-border marriages between the Chinese and African people. Therefore, many family issues such as divorce, guardianship of Children emerged frequently as a result. For example, one of the judgments that I collected from a South African Court concerning the right of the guardianship of their son between a South African mother and a Chinese father who celebrated their marriage in South Africa, ${ }^{14}$ one judgment made by a Lesotho court dealt with the divorce between a couple from Taiwan, ${ }^{15}$ and another judgment made by a Chinese court concerned the partition of the property situated in Lesotho between a Chinese couple who are petitioning divorce in that court. ${ }^{16}$

There are also judgments made by the Southern African courts concerning the separation of property and succession between the Chinese parties, or between the Chinese party and the African party, for instance, the judgment of Wang Yupu et Others v. P. Ranchod N.O. et Others made by a High Court in Zimbabwe, ${ }^{17}$ the judgment of Dong Pinghua, Dong Jinhua v. Zhang Zhaotai made by the High Court of Lesotho. ${ }^{18}$

As can be seen from above, that the civil and commercial disputes arising from the China-African business relations cover very broad legal issues. By the way, it should be mentioned here that there are also some criminal and administrative judgments made by the Southern African courts with the Chinese person or enterprise as one of the parties, though they will not be discussed here.

\section{THE FEATURES OF THE CIVIL AND COMMERCIAL DISPUTES ARISING FROM CHINA-AFRICAN BUSINESS RELATIONS}

The following observations can be made about the civil and commercial disputes arising from China-African business relations, based on the analysis of the judgments and the feedbacks

\footnotetext{
11 Dong Cheng v. Chinese Express SA (Pty) Ltd et Others, case No. 17/06/2008, in the High Court of South Africa (Transvaal Provincial Division).

${ }^{12}$ Societe Bic Trading Company Ltd v. Wenbara Trading Company Ltd et Others, HCT-00-CS-0704-2006, in the High Court of Uganda (Commercial Court Division).

${ }^{13}$ Mamathe Hanyane v. Zhaifeng Jiang et Others, CIV/APN/29/98, in the High Court of Lesotho.

${ }^{14}$ Elize Lin v. The Director: The Department of International Relations and Co-operation, case No. 3207/2010, in the High Court of South Africa (Eastern Cape, Port Elizabeth).

15 Weng Hsin-tui v. Weng Yeh Liya, CIV/t/351/99, in the High Court of Lesotho.

16 The Divorce Case between Qian Linchao and Zhang Xiaoming, Civil Judgement of Siming District People' Court, Xiamen, Fujian Province, China.

${ }^{17} \mathrm{HC} 2309 / 05$, in the High Court of Zimbabwe.

${ }^{18}$ CIV/APN/189/99, in the High Court of Lesotho.
} 
from the questionnaire:

\subsection{Most of the disputes occurred in African countries and were settled in the courts or arbitral institutions in Africa}

This is understandable because most African countries are the importing countries of Chinese goods and capital. In most cases, the contracts were performed in the African countries. So when disputes arising, the parties will often make resort to the courts or arbitral institutions in Africa.

Furthermore, the investment laws in many African countries expressly provide that the investment disputes between the foreign investor and the host country should first be settled in the courts or arbitral institutions in the host country. For example, the Petroleum Activities Law of Angola provides that in case of any disputes they should be resolved by arbitration taking place in Angola and governed by Angolan Law. ${ }^{19}$ This observation can be well illustrated by the following fact: from 2004 to the first half year of 2010, Egypt made 26 requirements for the service of judicial documents in civil and commercial matters to China, and at the same period, China only made 5 such requirements. ${ }^{20}$

\subsection{The disputes cover various African countries and involve different types of parties.}

At present, China has concluded bilateral trade agreements with 45 African countries and Chinese investments have spread in 49 African countries. ${ }^{21}$ The investors from China to Africa include not only the state-owned enterprises but also the non-state-owned enterprises and even the individuals. They invest in such a broad areas as mining, finance, manufacture, infrastructure, tourism and forestry, either on their own capital or on joint capital, or through stock-sharing, merger, cooperation with the third countries. Subsequently, the disputes will unavoidably involve different types of parties and occurred in various African countries. For example, the judgments collected from the Southern African courts involving the Chinese parties came from nearly every country in the region, with the parties being the individuals or the local companies controlled or wholly owned by the Chinese enterprises. Sometimes the Chinese state-owned enterprises or non-state-owned enterprises sue or are sued in their own names instead of the names of their local companies. ${ }^{22}$

\footnotetext{
${ }^{19}$ Oladiran Ajayi, Patricia Rosario, "Investments in Sub Saharan Africa: The Role of International Arbitration in Dispute Settlement". The author thanks Patricia Rosario for sending me a copy of this paper.

${ }^{20}$ Shen Hongyu, The Practice and Relevant Problems in the Judicial Assistance between China and African Countries, paper submitted to the Second China-African Legal Forum held in Beijing, September 15-19, 2010.

${ }^{21}$ The State Council Information Office of the People's Republic of China, White Paper on the China-African Business Cooperation (2010).

${ }^{22}$ Roosevelt Kgosi v. China Civil Engineering, in the Industrial Court of Botswana, case No. IC. 500/2004; China Henan Internal Economic and Technical Cooperation v. Mwange Contractors Limited (SCZ Judgement No. 7 of 2002), [2002] ZMSC 8 (24) January (2002); China Henan International Cooperation Group v. Regasira (civil
} 


\subsection{The lack of the effective bilateral or multilateral judicial assistance mechanism in civil and commercial matters between China and African countries often causes the long trial process.}

The adjudication of the civil and commercial disputes with foreign elements will generally require the service abroad of the judicial documents and taking evidence abroad. Sometimes the judgment creditor may have to seek the enforcement of the judgments in the country where the judgment debtor has its residence or property. These matters are usually provided in the bilateral judicial assistance treaties between two countries. Despite the frequent civil and commercial disputes between China and African countries, China has only concluded 4 judicial assistance treaties with Morocco, Egypt, Algeria and Tunisia. And the inefficiency in implementing the judicial assistance requirements according to the bilateral judicial treaties or non-implementation at all will easily result in the undue delay, or sometimes impossibility, of the trial process. For example, in the above 26 requirements for service from Egypt to China, only 14 judicial documents were effectively served by the relevant Chinese authority, and the average service time for each judicial document is 72.7 days; while as to the 5 requirements for service from China to Egypt, no proof of service has ever returned from the relevant Egyptian authority. $^{23}$

Additionally, the international judicial cooperation is now indispensable for the effective and efficient adjudication of the foreign-related cases. ${ }^{24}$ Accordingly, many multilateral conventions for such a purpose have been devised worldwide, for example the 1965 Hague Convention on the Service Abroad of Judicial and Extra-judicial Documents in Civil or Commercial Matters (hereinafter referred to as "Hague Convention on the Service Abroad") and the 1970 Hague Convention on the Taking of Evidence Abroad in Civil or Commercial Matters (hereinafter referred to as "Hague Convention on the Taking of Evidence Abroad"). The member states of such conventions may cooperate in the administration of justice under the mechanisms provided by such conventions. So far, China has acceded to the two Hague Conventions, but in Africa only Egypt, Botswana, Malawi and Seychelles acceded to the Hague Convention on the Service Abroad, and only South Africa and Seychelles became parties to the Hague Convention on the Taking of Evidence Abroad. Therefore, the cooperation between China and African countries in cases with foreign elements through the multilateral mechanisms is narrowly limited.

\subsection{The lack of the knowledge of each other's legal system between both parties will often cause the unnecessary delay of the settlement process.}

Though China-African civil and commercial transactions increase so frequently in recent years,

reference No. 22 of 2005) [2006] TZCA 43 (21 March 2006).

${ }^{23}$ Shen Hongyu, The Practice and Relevant Problems in the Judicial Assistance between China and African Countries, paper submitted to the Second China-African Legal Forum held in Beijing, September 15-19, 2010.

${ }^{24}$ Richard F. Oppong, Private International Law in Africa, the Past, Present and Future, 55 Am. J. Comp. L. 677, 2007, p.680. 
most of the Chinese people participating in such transactions do not know much about the legal systems in African countries, or even have some misunderstanding about the laws and judiciaries in African countries. Vice versa, Most African people doing business in China that I met with know little or nothing about the Chinese legal system. ${ }^{25}$ In case of dispute, they do not know what remedy can be resorted to immediately, or sometimes they will fear or worry to litigate or arbitrate in the other party's country, which will lead to the slow settlement process. ${ }^{26}$

The above analyses manifest a great unbalance in the China-African civil and commercial disputes, namely, most of the disputes originated in Africa, only a few of them occurred in China. This fact signifies the need for the Chinese parties to learn about the legal systems relating to the adjudication of the foreign-related cases in African countries.

\section{THE SETTLEMENT OF THE DISPUTES BETWEEN CHINESE AND AFRICAN PARTIES}

The adjudication of the foreign-related civil and commercial disputes is more complicated than the adjudication of the purely domestic civil and commercial disputes and they are also mainly settled through two ways: litigation and alternative dispute resolution such as consultation, mediation and arbitration.

The litigation of foreign-related disputes usually involve the jurisdiction, choice of law and the recognition and enforcement of foreign judgments. Great diversities existed in African legal systems, and there are some obstacles to settle such disputes through litigation in African courts, which can be summarized as follows:

First, few African Countries have ever made systematic and comprehensive codes encompassing all aspects of conflict of law issues. Among 53 African countries, only Tunisia adopted a systematic and comprehensive Private International Law Code in 1998, with detailed provisions about the international jurisdiction, choice of law, and the recognition and enforcement of foreign judgments. ${ }^{27}$ In other African countries, the private international law issues were stipulated in different single acts, which are hardly accessible.

Second, most of the legislations in this field in African countries are too old to suit the current situations or even inoperable due to some legislative technics. Most African countries transplanted the legal systems from their colonizing countries, but some of the legislations remain intact since their independence, which are outdated. Some African countries re-enacted

\footnotetext{
${ }^{25}$ Weidong ZHU, "China-African Trade \& Investment and the Exchange of Law", in Harmonization of Business Law in Africa and Its Advantage for Chinese Investment in Africa, Tipografia Macau Hung Heng Limitada, 2008, pp.99-113.

${ }^{26}$ China State Construction Engineering Corporation (Southern Africa) (Pty) Ltd v.Pro Joinery Close Corporation, in the High Court of Namibia, case No. A 230/2007.

${ }^{27}$ The content of this law is available at http://www.lexadin.nl/wlg/legis/nofr/oeur/lxwetun.htm.
} 
their laws to respond to the frequent transnational civil and commercial intercourses, but due to some technical reasons, the laws are inoperable. For example, the Enforcement of Foreign Judgments Act 32 of 1988 in South Africa provides that this act only applies to the recognition and enforcement of the judgments from the countries designated in South African Gazettes, whereas only Namibia is designated in the Gazette.

Third, the development of the rules dealing with the international civil and commercial litigation in some African countries is insulated from the international legal development. Nowadays, most countries permit the litigants to choose by agreement to litigate their disputes in a country which has no connections with the dispute, but the jurisdictional rules established in South Africa is, the South African court is incompetent to decide a dispute if the cause of action did not arise in South Africa, even if the foreign plaintiff and the foreign defendant have expressly agreed in their contract that the dispute should be settled in the South African court. ${ }^{28}$

And the last problem remains is that many conflict of laws issues are still waiting to be settled in Africa. After having examined over 300 judgments decided or reported in 13 Anglophone African countries from 1997 to 2007, An African private international law scholar pointed out that many uncertainties existed in many aspects in this field, which need to be developed by legislation or case law in future. ${ }^{29}$ The aspects include the choice of law in contract and tort, jurisdiction over activities on the Internet, and private international law problems arising from trust and intellectual property. ${ }^{30}$

While for most African countries, the alternative dispute resolution such as consultation, mediation and arbitration were not transplanted from western countries. As an informal dispute settlement method, arbitration has a long tradition in Africa. ${ }^{31}$ During the colonial period, many African countries enacted their arbitration laws based on the arbitration laws in their colonizing countries. After their independence, the old arbitration systems remained and revisions were made in accordance with the development in their former colonizing countries from time to time.

Since the 1990s, many African countries re-enacted their arbitration laws based on the advanced arbitration legal instruments, especially the 1985 UNCITRAL Model Law on International Commercial Arbitration (hereinafter referred as "Model Law") in order to attract foreign investment, expand the trade, and enhance the investors' confidence. Furthermore, Most of the African countries acceded to such international conventions on arbitration as the 1965 Washington Convention on the Settlement of Investment Disputes Between States and

\footnotetext{
${ }^{28}$ C F Forsyth, Private International Law: The Modern Roman-Dutch Law Including the Jurisdiction of the Supreme Courts, Juta \& Co Ltd, 3rd edition,1996, p.204.

${ }^{29}$ Richard F Oppong, A Decade of Private International Law in African Courts (1997-2007) (part I), vol.9, Yearbook of Private International Law, 2008, pp.224-225.

${ }^{30}$ Richard F. Oppong, Private International Law in Africa, the Past, Present and Future, 55 Am. J. Comp. L. 677, 2007, p.682.

${ }^{31}$ Eugene Contran and Austin Amissah, Arbitration in Africa, Kluwer Law International 1996, Preface.
} 
Nationals of Other States ("1965 Washington Convention") ${ }^{32}$ and the 1958 New York Convention on the Recognition and Enforcement of Foreign Arbitral Awards. ${ }^{33}$ On the other hand, many arbitral institutions or centers have been set up in African countries to provide the necessary facilities for effective and efficient arbitration in Africa. At present, nearly every African country has one arbitral institution or arbitral center. ${ }^{34}$

From the forgoing brief analysis of the dispute settlement mechanism in Africa, we can see that the laws in relation to foreign litigation in many African countries remain unsystematic, isolated from international development, and unsettled in many issues. There is another challenge for those who intend to litigate in African courts that the materials on international litigation in African countries are hardly accessible except those in South Africa. Therefore, the author proposes that arbitration should be the best option for the settlement of such disputes and a detailed analysis of the feasibility and construction of such a dispute settlement mechanism will be included in the author's another article in the forthcoming Journal of African Law. ${ }^{35}$

\section{CONCLUSION}

In the past few years the frequent legal disputes from China-African civil and commercial transactions have aroused the attention from both sides. The sound development of the civil and commercial transactions between both sides can only be guaranteed under a feasible and predictable legal framework. Only when the legal disputes are settled reasonably and lawfully, can the confidence to engage in the civil and commercial transactions be enhanced. Under the current legal systems and legal traditions in many African countries and in China, it is more preferable to settle such disputes through arbitration instead of through litigation for the Chinese parties as well as for the African parties doing business in China.

\footnotetext{
${ }^{32}$ Now 45 African States have signed the 1965 Washington Convention. Ethiopia, Guinea-Bissau, Namibia, Sao Tome and Principe only signed but not ratified the Convention, so 41 African states have been the Contracting States of the Convention. To see http://icsid.worldbank.org/ICSID/FrontServlet.
}

33 Now 30 African countries are parties to the New York Convention, to see http://www.uncitral.org/uncitral/en/uncitral_texts/arbitration/NYConvention_status.html, last visited 18 July.

${ }^{34}$ For a list of the names of arbitral institutions in Western Africa, to see T. Sutherland and G. Sezneck, "Alternative Dispute Resolution Services in West Africa: A Guide for Investors", sponsored by the Commercial Law Development Program United States Department of Commerce (2003), available at http://www.fdi.net/documents/WorldBank/databases/benin/westafricaguide7212003.pdf; for those in Sub-Sahara Africa, to see Emilia Onyema, "Regional Approaches to Enforcement: Enforcement of Arbitral Awards in Sub-Sahara Africa", paper presented at the Inaugural Conference of Alumni \& Friends of the School of Intenational Arbitration (AFSIA) London, 3 December 2008, available at: http://eprints.soas.ac.uk/5996/1/Enforcement_of_Awards_in_Sub-Sahara_Africa.pdf.

35 Weidong ZHU, Arbitration As the Best Option for the Settlement of China-African Trade and Investment Disputes, Journal of African Law (forthcoming: vol.57, no.1,2013). 


\section{REFERENCE}

[1] Amazu A. Asouzu, 2004, International Commercial Arbitration and African States, Cambridge: Cambridge University Press;

[2] Christopher Forsyth, 2003, Private International Law: the Modern Roman-Dutch Law Including the Jurisdictions of the High Courts, South Africa: Juta \& Co Ltd, 4th edition;

[3] Rudolf Dolzer and Christoph Schreuer, 2008, Principles of International Investment Law, Oxford: Oxford University Press;

[4] Deborah Brautigam, 2009, The Dragon's Gift: the Real Story of China in Africa, Oxford: Oxford University Press;

[5] Boris Martor, etc., 2007, Business Law in Africa: OHADA and the Unification Process, London: GMB Publishing Ltd;

[6] Weidong ZHU, 2008, “China-African Trade \& Investment and the Exchange of Law” , in Harmonization of Business Law in Africa and Its Advantage for Chinese Investment in Africa, ed by Salvatore Mancuso, Macau: Tipografia Macau Hung Heng Limitada; pp.99-113;

[7] Weidong ZHU, 2009, OHADA: As a Base for Chinese Further Investment in Africa” , Penant, vol.129, No.89, pp. 421-429 